\title{
SENSORY PROFILE OF PORTUGUESE WHITE WINES USING LONG-TERM MEMORY: A NOVEL NATIONWIDE APPROACH
}

\author{
ANIBAL JOSE-COUTINHO ${ }^{1,3}$, PATRICIA AVILA ${ }^{2}$ and JORGE M. RICARDO-DA-SILVA ${ }^{1}$ \\ ${ }^{1}$ Universidade de Lisboa, Instituto Superior de Agronomia, Laboratório Ferreira Lapa (Sector de Enologia), Tapada da Ajuda, $1349-017$ Lisbon, \\ Portugal \\ ${ }^{2}$ Instituto Universitário de Lisboa (ISCTE-IUL), Departamento de Métodos de Pesquisa Social, Av. das Forças Armadas, 1649-026 Lisbon, Portugal
}

${ }^{3}$ Corresponding author.

TEL: +351917223808;

Accepted for Publication July 20, 2015

doi:10.1111/joss.12165
EMAIL: ajosecoutinho@gmail.com

\begin{abstract}
White wine sensory profiling of all 12 Protected Geographical Indications (PGIs) of mainland Portugal was achieved through completion of extended sensory questionnaires by 20 professional wine experts. No samples were assessed; the experiment was based on memory alone. Three macro-zonings were found and typicality differences were statistically validated and sensory described. PGI MINHO was found the most typical of all PGIs, with several extreme rates on Color, Aroma and Taste. SOUTHERN cluster of the four meridional PGIs presented several extreme, therefore typical, sensory assessments, mostly opposite to the profile of PGI Minho. Color tonality, alcohol and acidity were mutually related and respective variations were correlated with published findings and expressed as key factors for regional macro-zoning differentiation. Moreover, with the proposed methodology it was possible to achieve a novel nationwide sensory characterization of PGIs, overcoming ongoing macroscaling and sample representativeness limitations and envisaging new nation-sized sensory studies.
\end{abstract}

\section{PRACTICAL APPLICATIONS}

This innovative nationwide study on white wine typicality, namely on sensory profiles of PGI (and PDO) certified wines, may contribute to the debate of scale factors that result in significant gains in areas such as wine certification (3-5 certification boards instead of existent 12), admission of transregional wine certification for high volume brands and a better and clearer communication and marketing that would reach a larger group of consumers with condensed information on typicality. Moreover, to develop a method that bypass the sampling problem of wines that would be representative of a given PGI or, in general, a nation-sized area may be considered useful and widely applicable to sensory studies.

\section{INTRODUCTION}

A wine is typical if some of its own characteristics can be identified and if it is recognizable as belonging to a regional or cultural type that is distinctive from others. In France, the concepts of the cru and terroir describe tasters' detection of regionality of wine (McCloskey et al. 1996). The perception of typicality may differentially affect purchase decisions (Jackson 2014). Results from the conjoint assessment of wine product concepts indicated that price and wine region were of greatest utility (Chrea et al. 2011). For all Protected Geographical Indications (PGI) and Protected Designation of Origin (PDO) products, quality control based on sensory parameters is fundamental for preserving the market position, maintaining consumer confidence, and loyalty, because perceived sensory characteristics represent the most important key factors for typicality of a product (Endrizzi et al. 2013).

A large number of sensory methodologies (Maitre et al. 2010) have been used with professional tasters to show the sensory properties of a wine category (wine variety or PDO). 
Scientists have tested different sensory approaches, although the perceptual methods based on sample tasting, such as Quantitative Descriptive Analysis (Perrin et al. 2008), Sorting Tasks (Parr et al. 2007) or Accreditation Methods (used by tasting panels from all Portuguese certification boards), may be considered the most commonly used. Moreover, qualitative methods can be applied to enhance quantitative studies (Jervis and Drake 2014).

Concerns regarding scarcity of samples assessed have always undermined the results on typicality. Do 6 (Ross et al. 2012), 10 (Vilanova 2006; Carlucci and Monteleone 2008), 13 (Varela and Gámbaro 2006), 17 (Runnebaum et al. 2011), 19 (Etaio et al. 2007), 20 (Scacco et al. 2007), or 23 (Campo et al. 2008) wine samples statistically represent and explain typicality over a vast wine region? This point of samples representativeness may be a concern for every one looking for characterizing wine typicality (Maitre et al. 2010). The production factors induce a great sensory diversity within the appellations, which leads to a problem of representativeness: having a wine labeled with a State appellation of origin is thus not sufficient to determine the sensory specificities of a given appellation and has to be distinguished from typicality (Perrin and Pagès 2009). Furthermore, if wine samples are tasted in quick succession, the increase in apparent astringency or the variability in alcohol content can produce tasting sequence errors (Jackson 2014). A recent study stated that a sample-tasting panel did not discriminate among the wines for astringency and bitterness, probably because the samples were inexpensive wines with very similar phenolic contents (Heymann et al. 2012).

Reducing sampling errors is vital for getting valid results from experiments and the level of expertise, as well as the kind, influences the performance and categorization. Despite the ongoing controversy, the role of expertise seems to be well documented. Researchers have described theories of wine expertise which highlight the importance of experience and long-term memory for extraordinary performance. Wine professionals (winemakers, wine journalists, etc) are often nonavailable for testing (Perrin et al. 2008), hence our experts were not formally trained, as usually done in quantitative descriptive analysis. Thanks to their high level of expertise, the abstraction of sensory prototypes is memorized and could be considered as a synthesis of all previous tasting experiences of samples from the category (Maitre et al. 2010). Therefore, this nationwide study was built on the case that senior experts have common mental representations of typical wines from each PGI, resulting in a feasible assessment of predetermined attributes and respective lexicon (Lawless and Civille 2013) which can be used to describe the sensory characteristics of a typical exemplar of the category or prototype. Clear agreement between experts concerning typicality scores (Ballester et al. 2008) and existence of shared cognitive constructs of typicality (Urdapilleta et al.
2011) have been demonstrated. Descriptions stored in longterm memory can be used to generate images of objects and scenes (Tempere et al. 2014). Flavor may be processed by tasters as a psychological construct, the data being more consistent with a perceptual/cognitive process rather than a consequence of rating strategies (Prescott 1999). The literature does not always clearly delineate what constitutes training and what is experience. Experience relates to a familiarity with a product class resulting from long term exposure to a wide variety of members representing that class (Gawel et al. 1997). Several studies indicate that the main difference between trained and untrained subjects is the quality of the vocabulary used (Chollet and Valentin 2000). Recognition of meaningful stimuli such as words or objects rapidly activates conceptual information and leads to the retrieval of additional relevant information from long-term memory (Potter 1993). If results suggest that wine expertise may be more of a cognitive skill rather than a perceptual one, and if all of the perceptually based techniques have a persistent low wine sampling hazard due to the logistical and/or timeconsuming factors, then why are not conceptual techniques, based on the long-term semantic memory from wine experts (Parr et al. 2002) and keepers of memory (Maitre et al. 2010), accepted and tested? The research interests in food science are diverse, and much of sensory research focuses on solving commodity-specific practical problems. Such research tends to act in a "traditional" way that prevents adopting new practices. Fundamental and innovative research, searching for general rules, explanations, and understanding are at risk, if applied testing is considered the primary obligation of the discipline. With adequate research questions and resources, sensory research can have significant implications across product categories (Tuorila and Monteleone 2009).

In 2012, 32\% of the total wine volume in Portugal was produced, certified and labeled as from a Protected Designation of Origin (PDO) and 23\% of that volume was from PGIs. Currently, there are 12 Protected Geographical Wine Indications (PGI) in mainland Portugal (Figure 1). For such a small country, does the actual range of 12 PGI's offer 12 single and typical wine sensory profiles, so different from one another that typicality governs consumers on their purchasing decisions?

Supporting evidence of the possible PGI's clustering feasibility can be found in bioclimatic (Magalhães et al. 1995; Fraga et al. 2013; Tonietto et al. 2014) and biogeographical zoning studies (Costa et al. 1990). Phenolic composition (Sun et al. 2001; Sun et al. 2013) and aroma (Vilanova and Vilarino 2006) exhibited zonal differences. Indeed, authentication of origin using elemental analysis has already been suggested (Rodrigues et al. 2011; Catarino et al. 2012).

In South Africa, differentiation between red wines according to geographical origin, based on selected chemical 
FIG. 1. PROTECTED GEOGRAPHICAL WINE REGIONS (AND RESPECTIVE INNER PDOS) IN MAINLAND PORTUGAL

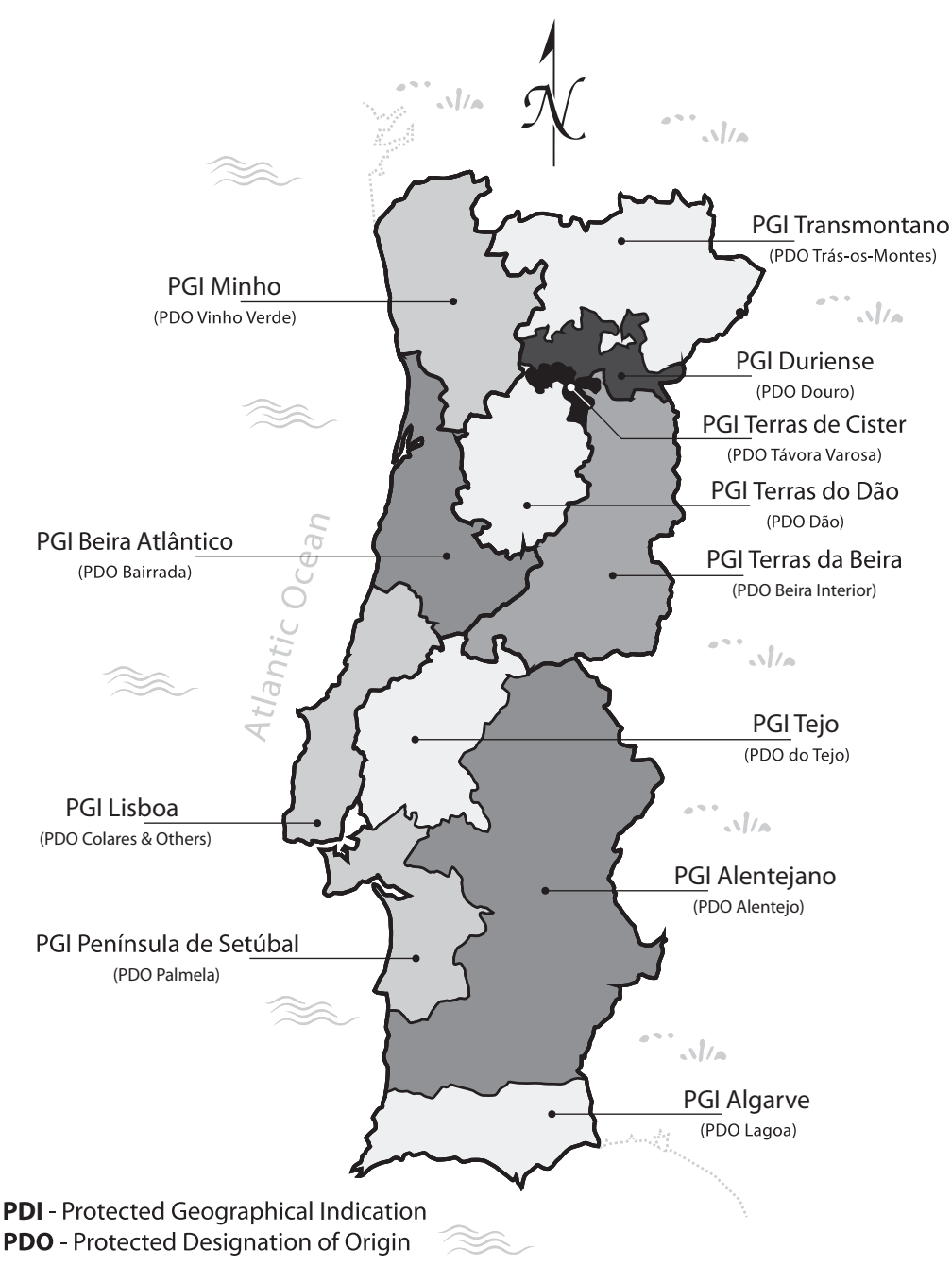

parameters was achieved (Minnaar and Booyse 2004). The impact of geographic origin, vintage and wine estate on sensory properties of German Riesling white wines was published (Fischer et al. 1999). Goldner and Zamora (2007) refer to studies that emphasize the geographical differentiation of wines, grapes or grapevines as the basis for zoning. To differentiate a single varietal (Chardonnay) along 4 Californian Appellations, 48 wines were assessed (McCloskey et al. 1996).

Research is showing that geographical origin of wine has strong impact on consumers (Hughson and Ashman 2004). Is it possible to get an agreement on sensory typicality inside a vast PGI or even in smaller Protected Designation of Origin (PDO) legally and geographically located inside a PGI? When there is a consensus, which methodology can be used to describe it? Those key questions remain scarcely answered. There has been no research on the sensory typicality of the current Portuguese PGÍs. To our knowledge, no nationwide sensory studies on both white and red PGI wines were yet published.
The aim of this study was determining which sensory descriptors are important to characterize white wine typicality on a nationwide scale. We also determined which aggregate variables allowed a significant discrimination in the different PGI white wines that might support and sensoryprofile the new found clustered macrozonings.

\section{MATERIALS AND METHODS}

\section{Expert Panel}

When compared with Parr et al. (2002) more stringent criteria were applied, as the definition of an expert considered the following categories:

Renowned winemakers with tasting activity of $>4$ times per week in at least 2 Portuguese wine regions;

Wine-science researchers and teaching staff who were regularly involved in wine-making and/or wine evaluation; 
NO TRACE

\begin{tabular}{|l|l|l|l|l|l|l|l|l|l|l|}
\hline & & & & & & & & & & \\
\hline 0 & 1 & 2 & 3 & 4 & 5 & 6 & 7 & 8 & 9 & 10 \\
\hline
\end{tabular}

EXTREMELY INTESE

HERBAL AROMA Intensity of minths, thyme, grass, infusions, anise, mediterranean bush, ...

NO TRACE

\begin{tabular}{|l|l|l|l|l|l|l|l|l|l|l|}
\hline & & & & & & & & & & \\
\hline 0 & 1 & 2 & 3 & 4 & 5 & 6 & 7 & 8 & 9 & 10 \\
\hline
\end{tabular}

EXTREMELY INTESE

FIG. 2. SHORT EXTRACT OF THE SENSORY QUESTIONNAIRE

Wine professionals (e.g., Master of Wine, wine judges, wine writers, and wine retailers);

Experts with an extensive ( $>15$ years) history of wine involvement.

Graduate wine students, wine consumers and enthusiasts, even with $>15$ years of wine involvement, were not considered amongst the group of professional wine experts.

The sensory output of this work was generated by 20 renowned winemakers, referenced scholars, opinion leaders and other professionals from the Portuguese wine industry. Recent literature showed that the number of panelists is well above the necessary to ensure a statistically robust outcome (Heymann et al. 2012).

\section{Questionnaire}

The questionnaire was designed according to the classical three-tier sensory method of assessment: visual, aromatic and gustatory/tactile attributes. Figure 2 shows an extract of the questionnaire, on which two aromatic variables are assessed on a 0 (no trace) to 10 (extremely intense) integer values scale (see full questionnaire on Supporting Information 1).

Color was assessed in its intensity and in its tonality, with categories for young white wines (Sáenz Gamasa et al. 2009). Aroma was evaluated with 1 overall intensity measure and 17 aromatic categories that summarize significant amount of scientific research (Ballester et al. 2009; Heymann et al. 2014), many of which are already used in the form of aroma wheels (Noble et al. 1987; Fischer et al. 1999; Lawless et al. 2012). The taste of white wines was evaluated with 13 measures, including essential tastes (sour, sweet, salty, bitter), mouthfeel categories resulting from various types of astringency (Pickering and Demiglio 2008; Oberholster et al. 2009) as well as burning, prickling, weight, persistence, and mouth-coat sensation (Jackson 2014).

Except for color tonality, the questionnaire used an 11integer points rating scale, anchored at the left "no trace of the attribute" (score 0) and at the right "extreme intensity of the attribute" (score 10). Color tonality results were standardized to match the same scale, as the previously reported research justified the use of a 3 integer points scale with 1 Yellow-Green, 2 Straw-Yellow, and 3 Yellow-Gold (Sáenz Gamasa et al. 2009).

\section{Procedure}

Respondents were invited by the same experimenter, after a short explanatory conversation, and received 12 questionnaires, one for each Portuguese wine PGI. They were asked to complete individually all 12 questionnaires in one week and send them by post to the experimenter.

The main question that the experts were expected to answer was "How would you define a typical young commercial white wine from this particular PGI and score each sensory attribute accordingly?" Despite some reasonable doubts on similar cognitive construct within the panel (Lawless 1997), no training phase or levelling pre-stage was performed. No wine samples were assessed. All experts independently completed individual questionnaires, characterizing each expert's own construct of what is a typical PGI young white wine of each of the 12 Portuguese wine regions by scoring several sensory attributes.

\section{Data Analysis}

Descriptive statistics (central tendency and dispersion) were computed for each sensory attribute (Scaman et al. 1998). Bivariate statistics, such as one-way ANOVA, were performed to reveal whether or not there exists an association, the strength of such an association or whether there is a difference between the sensory attributes, when the twelve PGIs are compared. This was followed by the completion of principal components analysis (PCA) with a varimax rotation which sought to explore the possibility of reducing the initial amount of sensory variables into fewer dimensions - the principal components (PC). Principal component analysis of sensory data permitted the differentiation among geographic areas (Vilanova and Soto 2005). The number of retained components was based on the Kaiser criterion (according to which the components with an eigenvalue greater than or equal to 1 are retained), and occasionally, the next principal component was also 
TABLE 1. LOADINGS OF 17 AROMATIC MEASURES IN THE FIRST SIX PRINCIPAL COMPONENTS. SELECTED AROMATIC CONTRIBUTORS TO EACH AGGREGATE PC ARE UNDERLINED

\begin{tabular}{|c|c|c|c|c|c|c|}
\hline \multirow[b]{2}{*}{ Aroma } & \multicolumn{6}{|c|}{ Components (by rotated component matrix) } \\
\hline & PC 1 & PC 2 & PC 3 & PC 4 & PC 5 & PC 6 \\
\hline Dried floral & $\underline{0.826}$ & -0.062 & 0.112 & -0.075 & 0.031 & 0.131 \\
\hline Nut fruit & $\overline{0.824}$ & 0.104 & -0.102 & -0.028 & 0.113 & 0.071 \\
\hline Jam \& Jelly fruit & $\overline{0.779}$ & 0.354 & -0.061 & 0.100 & 0.190 & 0.001 \\
\hline Dried fruit & 0.751 & 0.282 & -0.100 & -0.091 & -0.201 & -0.040 \\
\hline Ca ramelized & $\overline{0.615}$ & 0.456 & 0.125 & 0.211 & 0.200 & -0.185 \\
\hline Woody & $\overline{0.085}$ & $\underline{0.861}$ & 0.066 & 0.149 & -0.031 & -0.011 \\
\hline Bread \& Pastry & 0.263 & 0.787 & 0.118 & 0.123 & 0.077 & 0.088 \\
\hline Spicy & 0.470 & 0.565 & 0.208 & 0.059 & -0.291 & 0.046 \\
\hline Herbal & 0.044 & 0.017 & $\underline{0.888}$ & 0.167 & -0.107 & -0.001 \\
\hline Vegetal & -0.093 & 0.150 & $\overline{0.839}$ & 0.085 & -0.064 & -0.038 \\
\hline Chemical & 0.055 & 0.367 & 0.501 & -0.311 & 0.415 & 0.173 \\
\hline White fruit & 0.133 & 0.176 & $\overline{0.243}$ & $\underline{0.767}$ & 0.074 & -0.088 \\
\hline Citrus fruit & -0.264 & 0.188 & -0.026 & $\overline{0.723}$ & -0.118 & 0.341 \\
\hline Mineral & -0.021 & 0.158 & 0.290 & $\overline{0.269}$ & $-\underline{0.694}$ & 0.112 \\
\hline Tropical fruit & 0.060 & 0.207 & 0.031 & 0.313 & $\underline{0.630}$ & 0.349 \\
\hline Stone fruit & 0.492 & -0.105 & 0.098 & 0.415 & 0.533 & -0.167 \\
\hline Floral & 0.084 & 0.014 & -0.003 & 0.051 & $\overline{0.034}$ & $\underline{0.898}$ \\
\hline Total variance explained \% (cumulative) & $27.7(27.7)$ & $14.9(42.6)$ & $9.5(52.1)$ & $8.3(60.4)$ & $6.9(67.3)$ & $\overline{6.1(73.4)}$ \\
\hline
\end{tabular}

retained (Tables 1 and 2). Latent variables encompassing different initial variables found to be highly correlated on each PC were estimated, named accordingly and new descriptive statistics of the 12 PGIs was computed (see Table 3) on the basis of such aggregate latent variables (three initial variables were kept isolated: color intensity, color tonality and aromatic intensity). Given that the central hypothesis of this study anchored on the proximity of some regions in relation to their typical wine sensory profiles, global research of this proximity was assessed by hierarchical cluster analysis (HCA) which is an exploratory data analysis tool that aims at sorting different objects (the
12 PGIs) into groups in a way that the similarity between two objects is maximal if they belong to the same group and minimal otherwise. The squared Euclidean distance was taken as measure of the similarity between the different PGIs, and the complete linkage method algorithm was used to group the PGIs. Raw data from the above-mentioned three initial sensory variables excluded from the PCA, as well the means of the latent sensory variables that emerged from the PCA outcome were lined up as the HCA input. Clustered groups were, finally, sensory-described on the basis of mean scores comparison as the anova results confirmed the statistical robustness of our design (see Table 4).

TABLE 2. LOADINGS OF 13 TASTANT AND MOUTHFEEL DESCRIPTORS IN THE FIRST FOUR PRINCIPAL COMPONENTS. SELECTED TASTANT CONTRIBUTORS TO EACH AGGREGATE PC ARE UNDERLINED

\begin{tabular}{|c|c|c|c|c|}
\hline \multirow[b]{2}{*}{ Taste } & \multicolumn{4}{|c|}{ Components (by rotated component matrix) } \\
\hline & PC 1 & PC 2 & PC 3 & PC 4 \\
\hline Dry (mouthfeel) & 0.796 & 0.028 & 0.109 & 0.058 \\
\hline Astringent (global) & 0.772 & -0.001 & 0.119 & -0.047 \\
\hline Salty & 0.733 & 0.114 & -0.054 & 0.298 \\
\hline Rough (mouthfeel) & 0.730 & -0.208 & 0.274 & 0.048 \\
\hline Bitter & 0.713 & 0.095 & -0.029 & 0.170 \\
\hline Sweet & 0.123 & 0.850 & -0.145 & -0.161 \\
\hline Smooth (mouthfeel) & -0.077 & 0.804 & 0.329 & 0.086 \\
\hline Alcohol & 0.034 & $\overline{0.621}$ & 0.195 & -0.618 \\
\hline Length (persistence) & 0.243 & $-\overline{0.077}$ & $\underline{0.851}$ & 0.055 \\
\hline Oily (mouthcoat) & 0.090 & 0.500 & $\overline{0.653}$ & -0.320 \\
\hline Full body & 0.004 & 0.448 & $\overline{0.650}$ & -0.394 \\
\hline Bubbly & 0.240 & 0.046 & $-\overline{0.252}$ & 0.811 \\
\hline Acid (sour) & 0.326 & -0.389 & 0.292 & $\overline{0.659}$ \\
\hline Total variance explained \% (cumulative) & $23.5(23.5)$ & $18.7(42.2)$ & $15.3(57.6)$ & $1 \overline{4.6(72.2)}$ \\
\hline
\end{tabular}




\section{RESULTS AND DISCUSSION}

\section{Sensory Differentiation}

Twelve PGIs, memory assessed by the typicality of their respective PGI white wines, were sensory validated since all PGIs showed differences with significant statistical meaning (at least in 1 attribute) which was verified by the anova method, considering one fixed factor: the Geographical Indication. Multivariate statistical methods showed evidence of sensory aggregations between PGIs and extended geographical clusters or macrozonings with similar sensory profile were proposed. Relative Standard Deviation, also known as Coefficient of Variation (Abdi 2010), showed a lower percentage for the majority of the sensory attributes which indicates low variability in the data set means (see Table 2). The aggregate attributes PC1 Aoverripefruit, PC2 Awoodyspicy, PC1 Tbitterastringent showed high variability which may limit its interpretation.

\section{Representation of Aroma}

Except for the aromatic intensity assessment, the 17 initial aroma descriptors were grouped into six Principal Components (see Table 1) that were named according to the previously reported research on aromatic series: PC1 Aoverripefruit, PC2 Awoodyspicy, PC3 Agreenchemical, PC4 Awhitecitrus, PC5 Aripefruitmineral(-), PC6 AFloral (Stand Alone). It is interesting to note that the floral aromatic family stood alone as the key contributor of PC6 (explaining $6.1 \%$ of total variance). It is well known that floral-scented monoterpenic compounds are important to discriminate between grape varieties. This result may link to the fact that some Portuguese PGI have an important presence of Muscat grapes (Feliciano et al. 2009), and monoterpenic rich cultivars, such as Loureiro (Oliveira et al. 2004) or Fernão-Pires (Rocha et al. 2010).

It was possible to find an aggregate sensory measurement that explained $73.4 \%$ of total variance. The simplification procedure based on the expert panel assessments may prove to be optimal for macrozoning profiling purposes when compared to previously reported use of highly specific, isolated and less obvious sensory descriptors. This concern is finding increasing support within the scholar world itself (Quandt 2007).

\section{Representation of Taste}

The application of PCA to all tastant and mouthfeel categories aimed to simplify the characterization of the taste of PGI young white wines.

The 13 initial taste descriptors were finally grouped into four Principal Components Components (see Table 2) named accordingly to the classical tastes and contributing research on mouthfeel perceptions, reported above: PC1 Tbitterastringent, PC2 Tsweetalcohol, PC3 Tfullpersistent, and PC4 Tacidbubbly.

It was possible to find an aggregate sensory measurement that explained $72.2 \%$ of total variance, again supporting the possible role of the presented simplification procedure, namely on the tactile range of descriptors.

\section{Typical Wine Profiles Versus current PGIs}

The application of HCA has showed the existence of macrozoning sensory proximities which, partly, confirmed this research's initial hypothesis and, more importantly, validated the scope of the present assay.

The experts' typicality construct for the PGI white wines from mainland Portugal led to the outcome of 3 clusters (see Figs. 3 and 4) that were named according to their respective geography and a combination of geomorphological and bioclimatic aspects (Fraga et al. 2013):

- Cluster \#1: SOUTHERN (PGI Pen. Setubal (PS) + PGI Tejo (T) + PGI Alentejano (AL) + PGI Algarve (AG))

- Cluster \#2: CENTRAL COAST (PGI Beira Atlântico (BA) + PGI Lisboa (L)) + INLAND VALLEYS (PI Duriense + PGI Terras do Dão + PGI Terras Beira (TB) + PGI Transmontano (TM) + PGI Terras Cister (TC))

- (Single PGI) Cluster \#3: PGI MINHO (M)

The sensory profiles of white wines from the new-found clustered macrozonings zones in mainland Portugal were described and compared with published literature.

Sensory differences were found and proved to be in line with several published studies using other methodologies or focusing on partial sensory determinations. White wines, obtained by direct pressing with minimum skin contact, contain mostly the flavonoids originating from pulp. Nonflavonoid phenolic compounds (Rentzch et al. 2009), flavanol monomers, and oligomers have been found is small amounts (Ricardo-da-Silva et al. 1993). However, proanthocyanidin polymers have not been analyzed in white wines (Terrier et al. 2009). Wine phenolic derivatives may either taste astringent, bitter or both (Valentova et al. 2002). Due to the close relationship between bitterness and astringency (Lesschaeve and Noble 2005), our group of experts placed the major factor loadings for each sensation on the same principal component PC1 Tbitterastringent (see Table 4) which might be related to the low content of phenolic polymeric derivatives on white wine.

Typical Young White Wine Profile of the SOUTHERN Macrozoning. Final sensory attributes reveal some characteristics that sustain the fast clustering dynamics encompassing the 4 SOUTHERN PGIs (PGI 


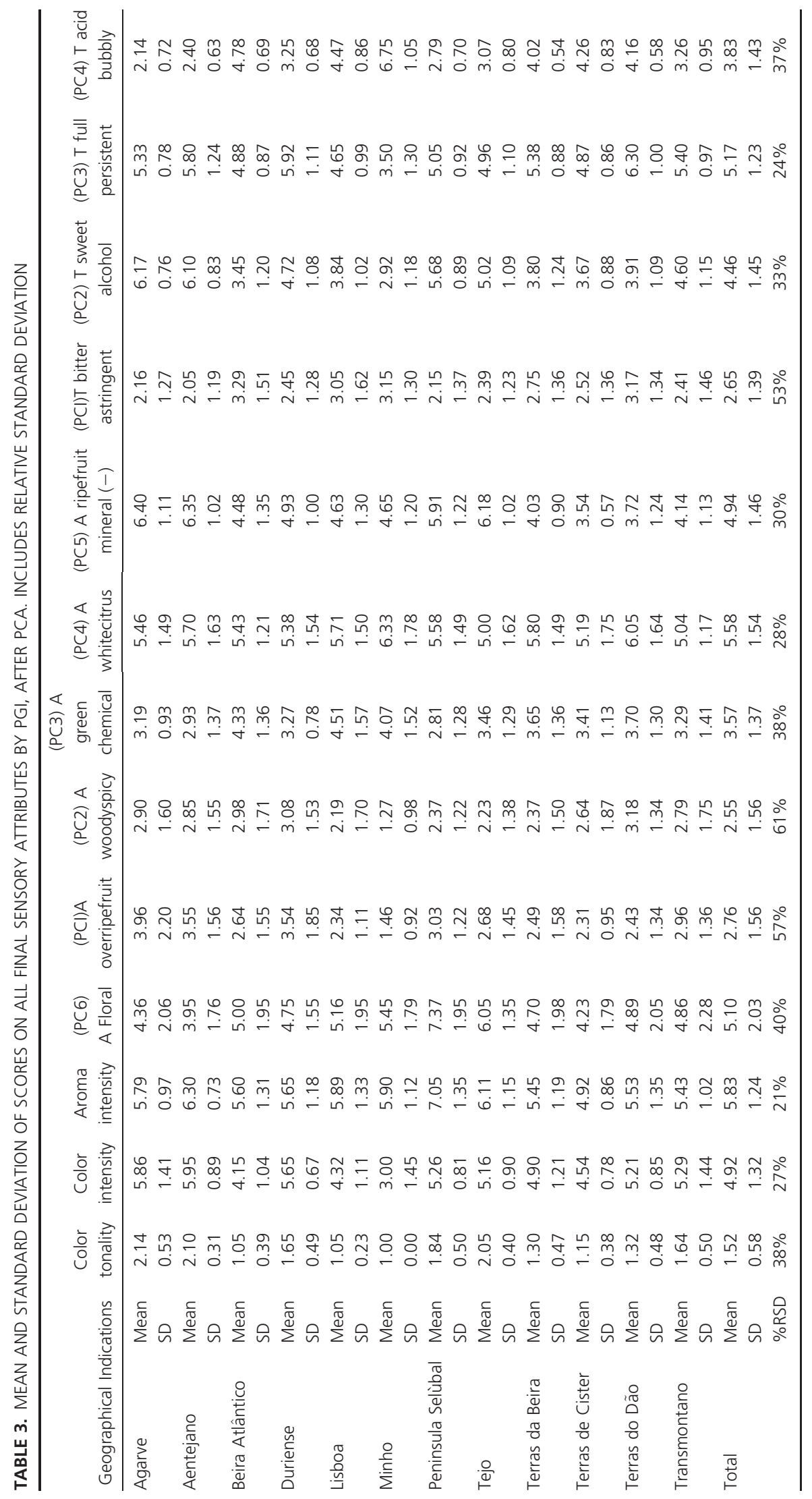




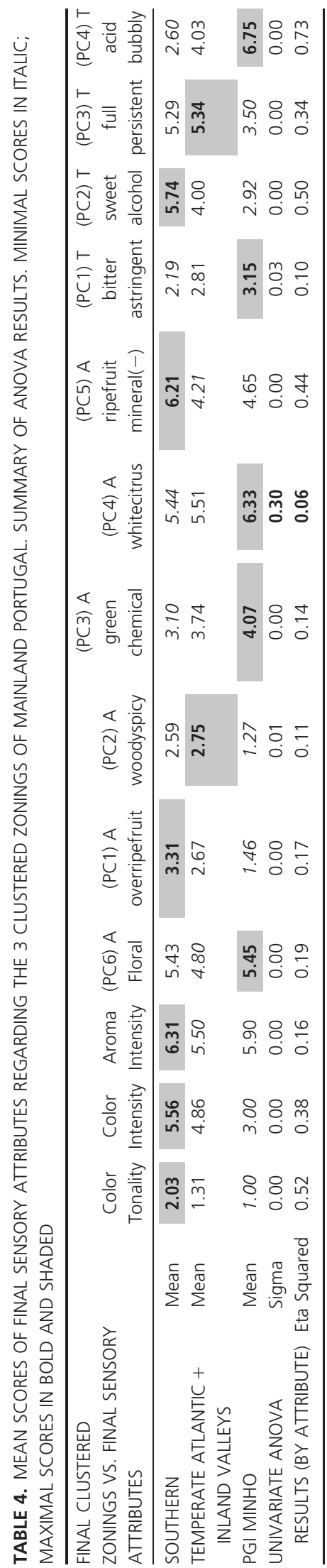

Peninsula de Setubal, PGI Tejo, PGI Alentejano and PGI Algarve), thus enabling the creation of a typical sensory profile for this macro-zoning (see Figs. 4 and 5). In line with our results, similar geoviticultural (temperate hot climate, temperate warm nights, moderate strong drought) and sensory (high alcohol, intense aromatic ripe fruity wines) grouping were reported for these same 4 PGIs (Climaco et al. 2012).

Color. Color (C) got the Top High assessment on C Tonality, indicating a Straw-Yellow hue, as well as the highest assessment on $C$ Intensity.

Mediterranean hot climate, especially warm nights, contributed to the increased intensity of color (Tonietto et al. 2014). Lower acidity levels are usually correlated with higher grape $\mathrm{pH}$, although the relation is affected by potassium accumulation, which is temperature dependent itself. At higher $\mathrm{pH}$ (lowest rating of PC4 Tacidbubbly) the formation of yellow or brown products due to the polymerisation of ortho-quinones is enhanced (Kallithraka et al. 2009), hence the straw-yellow color. Somehow comparable to higher maturations, a study showed that raisining decreased lightness and increased color saturation and tonality (FigueiredoGonzalez et al. 2013).

Aroma. Aroma got the Top Low assessment on PC3 Agreenchemical and PC4 Awhitecitrus. Inversely, Aroma intensity as well as PC1 Aoverripefruit, PC2 Awoodyspicy, and PC5 Aripefruitmineral(-) received the higher scores.

The aroma profile showed an intense raisin and jammy character with dominant tropical and stone fruit, but also woody, spicy, and young yeasty white fruit notes, maybe due to bigger ripeness and easier skin contact extraction. The SOUTHERN macrozoning ranked first on aromatic intensity and got the lowest scores on mineral and citrus and white fruit. Chemical and vegetal notes are almost inexistent. Inverse relations between green/vegetal and ripe fruit aromatic categories was already found on a New Zealand Sauvignon work on typicality (Parr et al. 2007). Furthermore, results indicate that a masking effect of vegetative aromas by fruit aromas occur (Hein et al. 2009).

Taste. Taste presented the lowest score on PC1 Tbitterastringent and on PC4 Tacidbubbly. Inversely, the SOUTHERN cluster got the highest score on PC2 Tsweetalcohol.

Taste characterization demonstrated clear typicality based on the sweetest palate, higher alcohol driven tactile sensations, weakness of fresh acidic taste and smooth mouthfeel. Lower perceptions of dry, astringent, rough tannin-related mouthfeel are frequent in these medium bodied southern white wines. Wines with high levels of polysaccharides tend to decrease the impact of bitterness and astringency (Carvalho et al. 2006). Bitterness and astringency are 


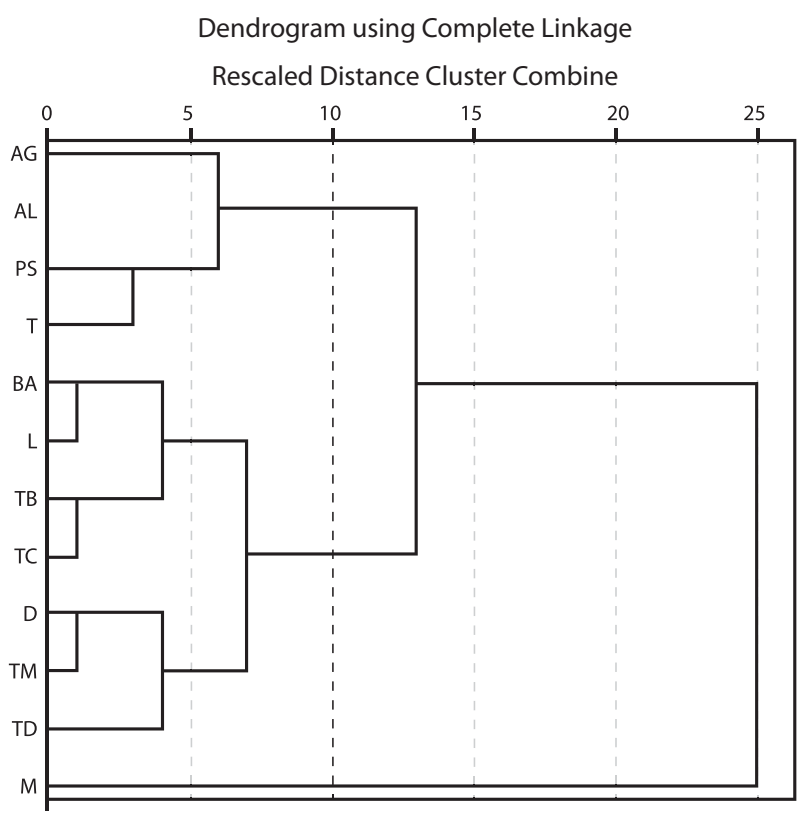

FIG. 3. DENDOGRAM SHOWING DISTANCE BETWEEN PGIS (TOPDOWN: AG, ALGARVE; AL, ALENTEJANO; PS, PENINSULA DE SETUBAL; T, TEJO; BA, BEIRA ATLANTICO; L, LISBOA; TB, TERRAS DA BEIRA; TC, TERRAS DE CISTER; D, DURIENSE; TM, TRANSMONTANO; TD, TERRAS DO DÃO; M, MINHO)

inversely correlated with high alcohol and sweet taste. Anecdotally, it is suggested that alcohol "sweet spots" exists (King and Heymann 2014). These findings are also consistent with previously published results from other researchers indicating that ethanol and glycerol do not significantly contribute to viscous mouthfeel (Runnebaum et al. 2011). A study indicates a slight synergy between ethanol and sugar on sweetness perception and an inhibition of ethanol and sugar perception on bitterness perception (Nurgel and Pickering 2006). Results of this study contradict reports of bitterness enhancement by alcohol (Fischer and Noble 1994) although some authors suggest that alcohol may supress the bitter taste when held in the mouth (Le Berre et al. 2007).

\section{Typical Young White Wine Profile of the CENTRAL} COAST \& INLAND VALLEYS (CCIV) Macrozoning. The entire inner center-northern Portugal was sensory-zoned, along with the temperate Atlantic PGIs (see Fig. 5). Curiously, the late PGI Beiras, encompassing the administrative merge of coastal and inner wine regions (PGI Terras da Beira (TB), PGI Terras de Cister (TC) and PGI Beira Atlântico (BA)), was officially extinct after the harvest of 2011.

Color. Color got an intermediate score on C Tonality, indicating a Green-Yellow-Straw hue and the same score on $C$ Intensity.

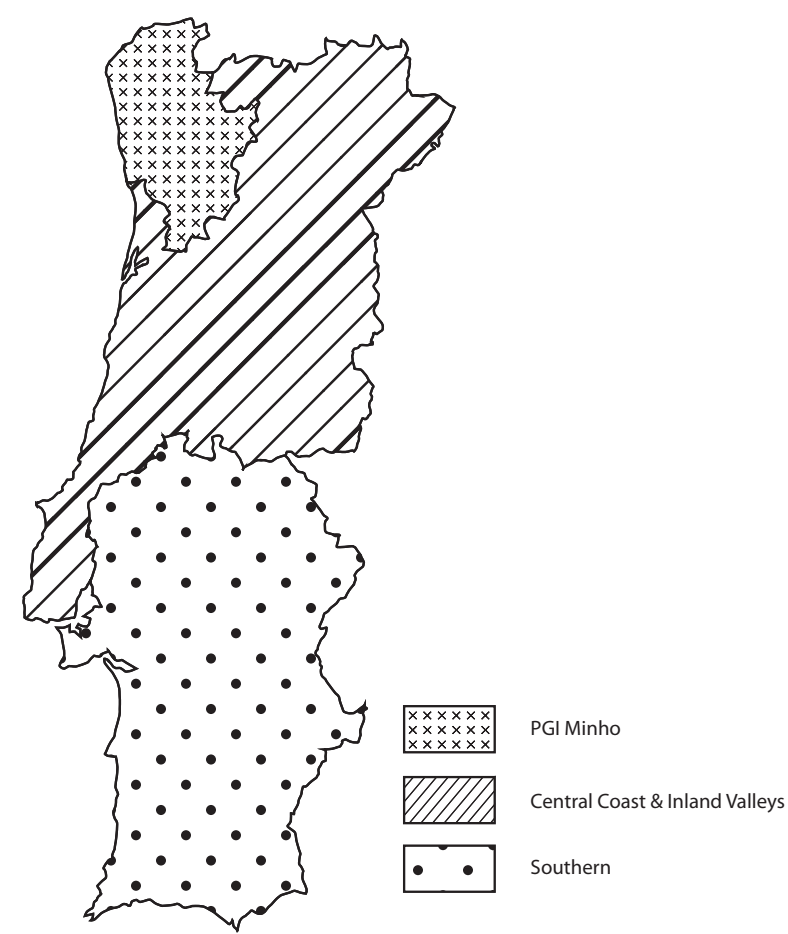

FIG. 4. THREE MACROZONING CLUSTERS FROM EXPERIMENTAL DESIGN ON SENSORY TYPICALITY

Color tonality is half-way from typical fresh and warm regions hues. In fact, this peripheral setting includes a vast macrozoning border which may explain the higher amplitude observed in our results. Some dominance of fresh/cool climate continental regions, with extreme thermal amplitudes explaining the fairly high color intensities (Mateus et al. 2002).

Aroma. Aroma showed strong typicality with one highest score on PC2 Awoodyspicy and three lowest ratings on overall aromatic intensity, floral aromas and PC5 Aripefruitmineral(-).

The mineral character (Heymann et al. 2014), as well as oak-related woody and spiced notes (Lawless et al. 2012; de Simon et al. 2008) related to extended secular oak management. The lowest perception of fruitiness and global intensity may derive from mutual suppression of a wider range of aromatic families (Jackson 2014), some acting in a competitive or even destructive way (Le Berre et al. 2007). Relation between the lower score of floral aromas and the scarce global aromatic intensity is somehow supported by the literature, as mutual enhancement is referred (Etaio et al. 2007).

Taste. Taste had a single but significant highest rating on PC3 Tfulpersistent and intermediate scores on remaining tastant PCs. Taste characterization showed typicality based on extremely long persistence, which relates with the 


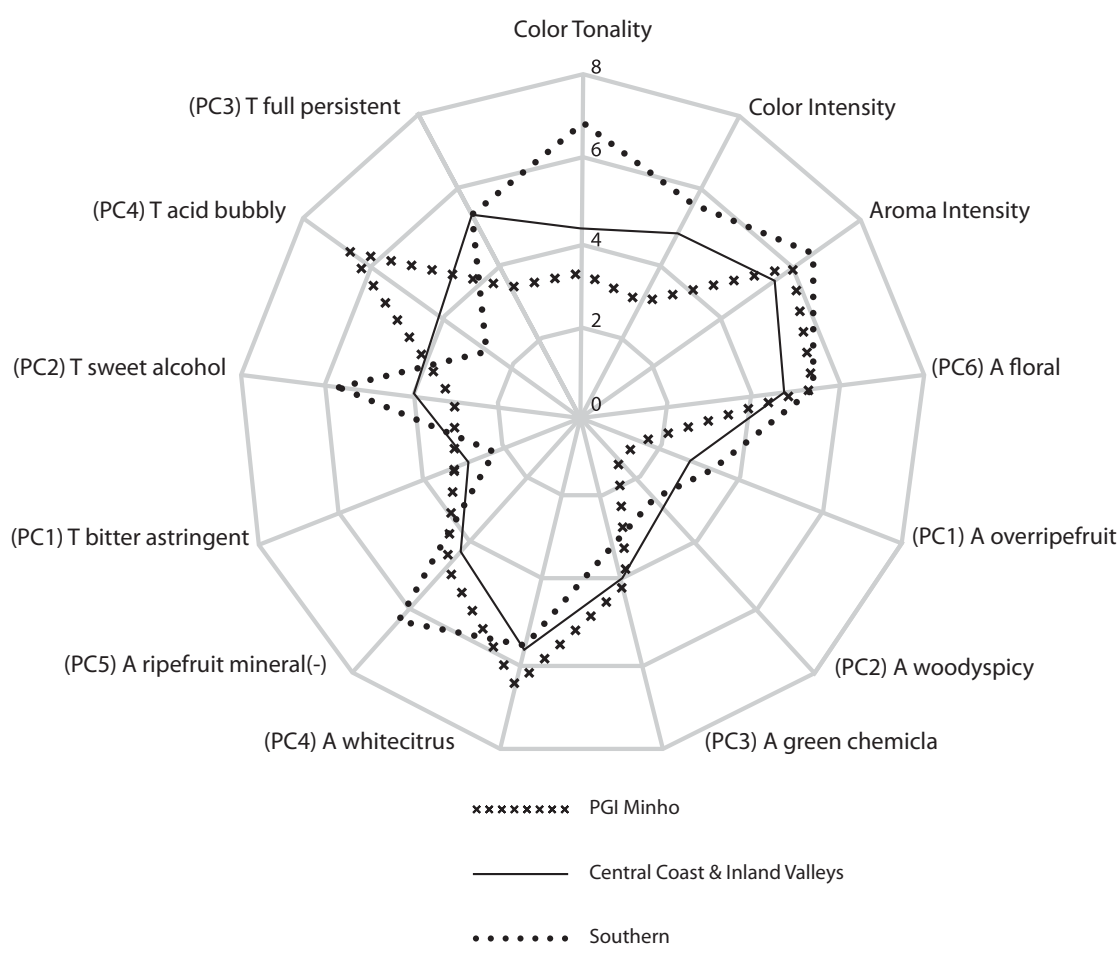

FIG. 5. WEB REPRESENTATION OF WHITE WINE SENSORY ATTRIBUTE MEANS PER IMMEDIATE CLUSTER highest assessment regarding fullness. This feature might relate to high grape density and phenolic content (Fernandes et al. 2010; Kontoudakis et al. 2011). Both the main yeast polysaccharides (mannoproteins) and principal grape polysaccharides (arabinogalactan-proteins and rhamnogalacturonans) increase the perception of body (Vidal et al. 2004). A study showed that the viscous mouthfeel of white wines is significantly correlated with physical properties, such as viscosity and osmotic potential, chemical properties, such as lactate, magnesium, and total extract (Runnebaum et al. 2011).

\section{Typical Young White Wine Profile of the Single- Clustered PGI MINHO. Northern-coastal PGI} MINHO_-wine region where the world's renowned PDO Vinho Verde is located-presented the highest primary typicality assessments. This result was strongly supported by 11 out of the 13 contributing variables showing extreme scores (see Table 2). Similar observations were previously reported by Climaco et al. (2012), based on applied geoviticultural multicriteria climatic classification system (Tonietto \& Carbonneau 2004) and sensory analysis.

Color. Color got the lowest score on $C$ Intensity and on $C$ Tonality indicating a Green-Yellow hue.

The highest assessment on PC4 Tacidbubbly correlates with the highest acidity levels, therefore with the lowest $\mathrm{pH}$, to explain the green-yellow non-oxidative hue (Li et al.
2008) which is typical of PGI Minho and related PDO Vinho Verde. Moreover, immature white grapes (Gómez-Míguez et al. 2007) yield almost colorless wines, whereas fully to overmature grapes may generate yellowish wines (Jackson 2014).

Aroma. Aroma may be considered extremely typical as the experts scored 3 Top High assessments (Floral aromas [PC6], PC3 Agreenchemical and PC4 Awhitecitrus) and 2 Top Lows (PC1 Aoverripefruit and PC2 Awoodyspicy).

The aromatic profile is built on several extreme assessments. The expressed high levels of green, chemical, citrus, and white fruit notes, as well as the low levels of overripe fruit, might relate to cool climate and low ripening conditions (Magalhães et al. 1995; Tonietto et al. 2014). Average intensity was found on PGI MINHO white wines, with extreme low presence of woody, spicy, and yeast pastry notes, certainly related to the fully unoaked and ready-drinking design of these wines. A floral intensity peak may be related to the prevalence of free or glycosylated terpenic-rich cultivars, such as Loureiro and Alvarinho (Oliveira et al. 2004).

Taste. TASTE may be considered extremely typical as the experts fully scored 2 Top High assessments on PC1 Tbitterastringent and PC4 Tacidbubbly, as well as 2 Top Low assessments on PC2 Tsweetalcohol and PC3 Tfullpersistent.

Located on the extreme northwest corner of mainland Portugal, the PGI MINHO sensory profile presented typical 
gustatory characteristics such as the highest intensity of dry, astringent and rough tannin mouthfeel related to greener ripeness (Sun et al. 2001). The highest assessment of astringency was found to occur on the low alcoholic wines (Fontoin et al. 2008). Inversely, these whites were assessed as light bodied wines with low persistence, low alcohol-driven tactile sensations as well as the lowest assessment on sweet and oily textures which may enhance sourness (Zamora et al. 2006). Maximal rate of fresh acidic taste is also typical of the PGI MINHO profile (see also Fig. 5). The fresh profile was amplified to its peak by the highest presence of bubbly sensations, mainly due to typical carbonic gas addition. Combination of the effect of excess acidity and astringency was termed Green by a panel of experienced wine-tasters (Gawel et al. 2001). Acidity appear to reduce the perception of body (Jackson 2014).

\section{CONCLUSIONS}

Although the results on wine typicality and territorial clustering might be considered encouraging in terms of future research within this unexplored macroscale sensory line of investigation, several vulnerabilities and limitations were stated and discussed. In this study, sensory profiling validity and results were found on the basis of a long-term memory construct of the whole array of attributes of Color, Aroma and Taste that characterise the expert's prototype of a typical white wine from a determined PGI. The absence of a direct testing experience and a calibration phase for lexicon and sensory perception represent significant and unusual oversteps on standard experimental design. Those concerns were mitigated with the stringent search for experimented senior wine experts, undisputed keepers of memory. Moreover, with the proposed methodology it was possible to achieve a novel nationwide sensory characterization of PGIs, overcoming ongoing macroscaling and sample representativeness limitations. Also, a new large-scale mapping design was achieved as three macro-zonings, clustering all 12 mainland Portugal PGIs, were found and typicality differences were statistically validated and sensory described. PGI Minho showed as the most typical of all PGIs, with several extreme rates on Color, Aroma and Taste. SOUTHERN cluster of the four meridional PGIs presented several extreme sensory assessments, mostly opposite to the northwest-coastal profile of PGI Minho. Color tonality, alcohol and acidity were mutually related and respective variations were expressed as key profilers for regional macrozoning differentiation.

In a small country such as Portugal, encompassing a low yield viticulture and a dominance of old vines in small parcels owned by even smaller producers, scientific research studies on macrozoning, namely on sensory profiles of PGI (and PDO) certified wines, may be considered of added value and contribute to the debate of scale factors that might result in significant gains in areas such as wine certification (3-5 certification boards instead of existent 12), admission of trans-regional wine certification for high volume brands and a better and clearer communication and marketing that would reach a larger group of consumers with condensed information on typicality.

\section{REFERENCES}

ABDI, H. 2010. Coefficient of variation. Encyclopedia of Research Design, pp. 1-5, SAGE.

BALLESTER, J., PATRIS, B., SYMONEAUX, R. and VALENTIN, D. 2008. Conceptual vs. perceptual wine spaces: Does expertise matter? Food Qual. Prefer. 19, 267-276.

BALLESTER, J., ABDI, H., LANGLOIS, J., PEYRON, D. and VALENTIN, D. 2009. The odor of colors: Can wine experts and novices distinguish the odors of white, red, and rosé wines? Chemosensory Percept. 2, 203-213.

LE BERRE, E., ATANASOVA, B., LANGLOIS, D., ETIÉVANT, P. and THOMAS-DANGUIN, T. 2007. Impact of ethanol on the perception of wine odorant mixtures. Food Qual. Prefer. 18, 901-908.

CAMPO, E., DO, B.V., FERREIRA, V. and VALENTIN, D. 2008. Aroma properties of young Spanish monovarietal white wines: A study using sorting task, list of terms and frequency of citation. Australian J. Grape Wine Res. 14, 104-115.

CARLUCCI, A. and MONTELEONE, E. 2008. A procedure of sensory evaluation for describing the aroma profile of single grape variety wines. J. Sensory Studies 23, 817-834.

CARVALHO, E., MATEUS, N., PLET, B., PIANET, I., DUFOURC, E. and DE FREITAS, V. 2006. Influence of wine pectic polysaccharides on the interactions between condensed tannins and salivary proteins. J. Agric. Food Chem. 54, 8936-8944.

CATARINO, S., MADEIRA, M., MONTEIRO, F., TRANCOSO, I.M., MARTINS, P., BRUNO-DE-SOUSA, R. and CURVELOGARCIA, A.S. 2012. Geographical origin of wines based on elemental composition. XXXIVth World Congress of Vine and Wine General Assembly of OIV, Porto.

CHOLLET, S. and VALENTIN, D. 2000. Impact of training on beer flavor perception and description: Are trained and untrained subjects really different? J. Sensory Studies 16, 601-618.

CHREA, C., MELO, L., EVANS, G., FORDE, C., DELAHUNTY, C. and COX, D.N. 2011. An investigation using three approaches to understand the influence of extrinsic product cues on consumer behavior: An example of Australian wines. J. Sensory Studies 26, 13-24.

CLIMACO, P., RICARDO-DA-SILVA, J., LAUREANO, O., CASTRO, R. and TONIETTO, J. 2012. O Clima Viticola das Principais Regioes Produtoras de Uvas para Vinho de Portugal. O Clima Viticola das Principais Regioes Produtoras de Uvas para Vinho de Portugal, Madrid.

COSTA, J.C., AGUIAR, C., CAPELO, J.H., LOUSÃ, M. and NETO, C. 1990. Biogeografia de Portugal Continental, Quercetea. 
ENDRIZZI, I., APREA, E., BIASIOLI, F., COROLLARO, M.L., DEMATTÈ, M.L., PENASA, M., BITTANTE, G. and GASPERI, F. 2013. Implementing sensory analysis principles in the Quality control of PDO products: A critical evaluation of a real-world case study. J. Sensory Studies 28, 14-24.

ETAIO, I., ALBISU, M., GASTON, E., OJEDA, M. and SCHLICH, P. 2007. The description of young red wines from. J. Sensory Studies 23, 631-655.

FELICIANO, R.P., BRAVO, M.N., PIRES, M.M., SERRA, A.T., DUARTE, C.M., BOAS, L.V. and BRONZE, M.R. 2009. Phenolic content and antioxidant activity of moscatel dessert wines from the setúbal region in portugal. Food Anal. Methods 2, 149-161.

FERNANDES, P., RICARDO-DA-SILVA, J.R. and CASTRO, R. 2010. Comportamento Agronómico e Enológico das Castas Syrah e Touriga Nacional em seis “Terroirs" de Portugal. $8^{\circ}$ Simpósio de Vitivinicultura do Alentejo, Évora, pp. 143-153.

FIGUEIREDO-GONZALEZ, M., CANCHO-GRANDE, B. and SIMAL-GANDARA, J. 2013. Evolution of colour and phenolic compounds during Garnacha Tintorera grape raisining. Food Chem. 141, 3230-3240.

FISCHER, U. and CHRISTMANN, M., ET AL. 1999.

Development of an Aroma Wheel for German White and Red Wines. 24th OIV World Vine and Wine Congress, pp. 201-207, Mainz.

FISCHER, U. and NOBLE, A.C. 1994. The effect of ethanol, catechin concentration and $\mathrm{pH}$ on sourness and bitterness of wine. Am. J. Enol. Vitic. 45, 6-10.

FISCHER, U., ROTH, D. and CHRISTMANN, M. 1999. The impact of geographic origin, vintage and wine estate on sensory properties of Vitis vinifera cv. Riesling wines. Food Qual. Prefer. 10, 281-288.

FONTOIN, H., SAUCIER, C., TEISSEDRE, P.L. and GLORIES, Y. 2008. Effect of pH, ethanol and acidity on astringency and bitterness of grape seed tannin oligomers in model wine solution. Food Qual. Prefer. 19, 286-291.

FRAGA, H., MALHEIRO, A.C., MOUTINHO-PEREIRA, J., JONES, G.V., ALVES, F., PINTO, J.G. and SANTOS, J.A. 2013. Very high resolution bioclimatic zoning of Portuguese wine regions: Present and future scenarios. Reg. Environ. Ch. 14, 295-306.

GAWEL, R., CAMPUS, W. and OSMOND, G. 1997. The use of language by trained and untrained experienced wine tasters. J. Sensory Studies 12, 267-284.

GAWEL, R., ILAND, P.G. and FRANCIS, I.L. 2001. Characterizing the astringency of red wine: A case study. Food Qual. Prefer. 12, 83-94.

GOLDNER, M.C. and ZAMORA, M.C. 2007. Sensory characterization of vitis vinifera $\mathrm{cv}$. Malbec wines from seven viticulture regions of Argentina. J. Sensory Studies 22, 520-532.

GÓMEZ-MÍGUEZ, M., VICARIO, I.M. and HEREDIA, F.J. 2007. Assessment of colour and aroma in white wines vinifications: Effects of grape maturity and soil type. J. Food Eng. 79, 758764.
HEIN, K., EBELER, S.E. and HEYMANN, H. 2009. Perception of fruity and vegetative aromas in red wine. J. Sensory Studies 24, 441-455.

HEYMANN, H., MACHADO, B., TORRI, L. and ROBINSON, A.L. 2012. How many judges should one use for sensory descriptive analysis? J. Sensory Studies 27, 111-122.

HEYMANN, H., HOPFER, H. and BERSHAW, D. 2014. An exploration of the perception of minerality in white wines by projective mapping and descriptive analysis. J. Sensory Studies 29, 1-13.

HUGHSON, A. and ASHMAN, H. 2004. Mind-sets of the wine consumer. J. Sensory Studies 19, 85-105.

JACKSON, R.S. 2014. Wine Science, Academic Press, 831-888.

JERVIS, M.G. and DRAKE, M.A. 2014. The use of qualitative research methods in quantitative science: A review. J. Sensory Studies 29, 234-247.

KALLITHRAKA, S., SALACHA, M.I. and TZOUROU, I. 2009. Changes in phenolic composition and antioxidant activity of white wine during bottle storage: Accelerated browning test versus bottle storage. Food Chem. 113, 500-505.

KING, E.S. and HEYMANN, H. 2014. The effect of reduced alcohol on the sensory profiles and consumer preferences of white wine. J. Sensory Studies 29, 33-42.

KONTOUDAKIS, N., GONZALEZ, EI., GIL, M., ESTERUELAS, M., FORT, F., MIQUEL-CANALS, J. and ZAMORA, F. 2011. Influence of the heterogeneity of grape phenolic maturity on wine composition and quality. Food Chem. 124, 767-774.

LAWLESS, H. 1997. Evaluation of wine quality using a small panel hedonic scaling method. J. Sensory Studies 12, 317-332.

LAWLESS, L.J.R. and CIVILLE, G.V. 2013. Developing lexicons: A review. J. Sensory Studies 28, 270-281.

LAWLESS, L.J.R., HOTTENSTEIN, A. and ELLINGSWORTH, J. 2012. The McCormick spice wheel: A systematic and visual approach to sensory lexicon development. J. Sensory Studies 27, 37-47.

LESSCHAEVE, I. and NOBLE, A.C. 2005. Polyphenols: Factors influencing their sensory properties and their effects on food and beverage preferences. Am. J. Clin. Nutr. 81(1 Suppl), 330S-335S.

LI, H., GUO, A. and WANG, H. 2008. Mechanisms of oxidative browning of wine. Food Chem. 108, 1-13.

MAGALHÃES, N., OLIVEIRA, A. and CAEIRO, L. 1995. Contributo para a caracterização climática das Regiões Vitícolas de Portugal Continental. $3^{\circ}$ Simpósio de Vitivinicultura do Alentejo. Évora, pp. 81-90.

MAITRE, I., SYMONEAUX, R., JOURJON, F. and MEHINAGIC, E. 2010. Sensory typicality of wines: How scientists have recently dealt with this subject. Food Qual. Prefer. 21, 726-731.

MATEUS, N., MACHADO, J.M. and DE FREITAS, V. 2002. Development changes of anthocyanins in Vitis vinifera grapes grown in the Douro Valley and concentration in respective wines. J. Sci. Food Agric. 82, 1689-1695.

MCCLOSKEY, L.P., SYLVAN, M. and ARRHENIUS, S.P. 1996. Descriptive analysis for wine quality experts determining 
appellations by Chardonnay wine aroma. J. Sensory Studies 11, $49-67$.

MINNAAR, P.P. and BOOYSE, M. 2004. Differentiation between wines according to geographical Regions in the Western Cape (South Africa) using multivariate analyses based on selected chemical parameters in young red wines. South Afr. J. Enol. Vitic. 25, 89-93.

NOBLE, A.C., ARNOLD, R.A., BUECHSENSTEIN, J., LEACH, E.J., SCHMIDT, J.O. and STERN, P.M. 1987. Modification of a standardized system of wine aroma terminology. Am. J. Enol. Vitic. 38, 143-146.

NURGEL, C. and PICKERING, G. 2006. Modeling of sweet, bitter and irritant sensations and their interactions elicited by model ice wines. J. Sensory Studies 21, 505-519.

OBERHOLSTER, A., FRANCIS, I.L., ILAND, P.G. and WATERS, E.J. 2009. Mouthfeel of white wines made with and without pomace contact and added anthocyanins. Aust. J. Grape Wine Res. 15, 59-69.

OLIVEIRA, J.M., ARAÚJO, I.M., PEREIRA, O.M., MAIA, J.S., AMARAL, A.J. and MAIA, M.O. 2004. Characterization and differentiation of five "vinhos Verdes" grape varieties on the basis of monoterpenic compounds. Anal. Chim. Acta 513, 269-275.

PARR, W.V., GREEN, J.A, WHITE, K.G. and SHERLOCK, R.R. 2007. The distinctive flavour of New Zealand Sauvignon blanc: Sensory characterisation by wine professionals. Food Qual. Prefer. 18, 849-861.

PARR, W.V., HEATHERBELL, D. and WHITE, K.G. 2002. Demystifying wine expertise: Olfactory threshold, perceptual skill and semantic memory in expert and novice wine judges. Chem. Senses 27, 747-755.

PERRIN, L., SYMONEAUX, R., MAITRE, I., ET AL. 2008. Comparison of three sensory Napping (R) procedure: Case of methods for use with the ten wines from Loire valley. Food Qual. Prefer. 19, 1-11.

PERRIN, L. and PAGÈS, J. 2009. A methodology for the analysis of sensory typicality judgments. J. Sensory Studies 24, 749-773.

PICKERING, G.J. and DEMIGLIO, P. 2008. The white wine mouthfeel wheel: A Lexicon for describing the oral sensations elicited by white wine. J. Wine Res. 19, 51-67.

PICLIN, N., PINTORE, M., LANZA, C., SCACCO, A., GUCCIONE, S., GIURATO, L. and CHRÉTIEN, J.R. 2007. Sensory analysis of red wines: Discrimination by adaptive fuzzy partition. J. Sensory Studies 23, 558-569.

POTTER, M.C. 1993. Very short-term conceptual memory. Memory Cogn. 21, 156-161.

PRESCOTT, J. 1999. Flavour as a psychological construct: Implications for perceiving and measuring the sensory qualities of foods. Food Qual. Prefer. 10, 349-356.

QUANDT, R. 2007. On wine bullshit: Some new software? J. Wine Econ. 2, 129-135.

RENTZCH, M., WILKENS, A. and WINTERHALTER, P. 2009. Non-flavonoid phenolic compounds. Wine Chemistry and Biochemistry, pp. 509-527, Springer.
RICARDO-DA-SILVA, J.M., CHEYNIER, V., SAMSON, A. and BOURZEIX, M. 1993. Effect of pomace contact, carbonic maceration and hyperoxidation on the procyanidin composition of grenache blanc wines. Am. J. Enol. Vitic. 44, 168-172.

ROCHA, S.M., COUTINHO, P., COELHO, E., BARROS, A.S., DELGADILLO, I. and COIMBRA, M.A. 2010. Relationships between the varietal volatile composition of the musts and white wine aroma quality. A four year feasibility study. LWTFood Sci. Technol. 43, 1508-1516.

RODRIGUES, S.M., OTERO, M., ALVES, A.A., COIMBRA, J., COIMBRA, M.A., PEREIRA, E. and DUARTE, A.C. 2011.

Elemental analysis for categorization of wines and authentication of their certified brand of origin. J. Food Comp. Anal. 24, 548-562.

ROSS, C.F., WELLER, K.M. and ALLDREDGE, J.R. 2012. Impact of serving temperature on sensory properties of red wine as evaluated using projective mapping by a trained panel. J. Sensory Studies 27, 463-470.

RUNNEBAUM, R.C., BOULTON, R.B., POWELL, R.L. and HEYMANN, H. 2011. Key constituents affecting wine bodyan exploratory study. J. Sensory Studies 26, 62-70.

SÁENZ GAMASA, C., HERNÁNDEZ, B., SANTIAGO, J.V., ALBERDI, C., ALFONSO, S. and DIÑEIRO, J.M. 2009. Measurement of the colour of white and rosé wines in visual tasting conditions. Eur. Food Res. Technol. 229, 263-276.

SCAMAN, C.H., DOU, J., CLIFF, M.A., YUKSEL, D. and KING, M.C. 1998. Evaluation of wine competition judge performance using principal component similarity analysis. J. Sensory Studies 16, 287-300.

DE SIMON, B.F., CADAHÍA, E., SANZ, M., POVEDA, P., PEREZ-MAGARIÑO, S., ORTEGA-HERAS, M. and GONZÁLEZ-HUERTA, C. 2008. Volatile compounds and sensorial characterization of wines from four Spanish denominations of origin, aged in Spanish Rebollo (Quercus pyrenaica Willd.) oak wood barrels. J. Agric. Food Chem. 56, 9046-9055.

SUN, B., SA, M., LEANDRO, C., CALDEIRA, I., DUARTE, F. and SPRANGER, M.I. 2013. Reactivity of Polymeric Proanthocyanidins toward Salivary Proteins. J. Agric. Food Chem. 61, 939-946.

SUN, B., RICARDO-DA-SILVA, J.M. and SPRANGLER, M.I. 2001. Quantification of Catechins and Proanthocyanidins in several Portuguese garpevine varieties and red wines. Ciencia e Tecnica Vitivinicola, 16, 23-34.

TEMPERE, S. HAMTAT, M.L., BOUGEANT, J.C. DE REVEL, G. and SICARD, G. 2014. Learning odors: The impact of visual and olfactory mental imagery training on odor perception. J. Sensory Studies 29, 435-449.

TERRIER, N., PONCET-LEGRAND, C. and CHEYNIER, V. 2009. Flavanols, flavovols and dihydroflavonols. Wine Chemistry and Biochemistry. Springer, 463-507.

TONIETTO, J. ET AL. 2014. The effect of viticultural climate on red and white wine typicity. Characterization in IberoAmerican grape-growing regions. J. Int. de la Sci. de la Vigne et du Vin, (Special Laccave), 19-23. 
TONIETTO, J. and CARBONNEAU, A. 2004. A multicriteria climatic classification system for grape-growing regions worldwide. Agric. Forest Meteorol. 124, 81-97.

TUORILA, H. and MONTELEONE, E. 2009. Sensory food science in the changing society: Opportunities, needs, and challenges. Trends Food Sci Technol 20, 54-62.

URDAPILLETA, I., PARR, W., DACREMONT, C. and GREEN, J. 2011. Semantic and perceptive organisation of Sauvignon blanc wine characteristics: Influence of expertise. Food Qual. Prefer. 22, 119-128.

VALENTOVA, H., SKROVANKOVA, S., PANOVSKA, Z. and POKORNY, J. 2002. Time-intensity studies of astringent taste. Food Chem. 78, 29-37.

VARELA, P. and GÁMBARO, A. 2006. Sensory descriptive analysis of Uruguayan Tannat wine: Correlation to quality assessment. J. Sensory Studies 21, 203-217.

VIDAL, S., FRANCIS, L., WILLIAMS, P., KWIATKOWSKI, M., GAWEL, R., CHEYNIER, V. and WATERS, E. 2004. The mouth-feel properties of polysaccharides and anthocyanins in a wine like medium. Food Chem. 85, 519-525.

VILANOVA, M. 2006. Acceptability of Godello Wines From Valdeorras. J. Sensory Studies 21, 362-372.

VILANOVA, M. and SOTO, B. 2005. The impact of geographic origin on sensory properties of. J. Sensory Studies 20, 503-511.

VILANOVA, M. and VILARINO, F. 2006. Influence of geographic origin on aromatic descriptors of Spanish Albarino wine. Flavour Fragrance J. 21, 373-378.

ZAMORA, M.C., GOLDNER, M.C. and GALMARINI, M.V. 2006. Sourness - Sweetness interactions in different media: White wine, ethanol and water. J. Sensory Studies 21, 601-611.

\section{SUPPORTING INFORMATION}

Additional Supporting Information may be found in the online version of this article. 
Copyright of Journal of Sensory Studies is the property of Wiley-Blackwell and its content may not be copied or emailed to multiple sites or posted to a listserv without the copyright holder's express written permission. However, users may print, download, or email articles for individual use. 